\title{
Lula, the Workers' Party and the Governability Dilemma in Brazil*
}

\author{
by Rachel Meneguello \\ Universidade Estadual de Campinas, Brazil
}

\section{(Gómez Bruera, Hernán F. Lula, the Workers' Party and the Governability Dilemma in Brazil. New York: Routledge, 2013)}

66 ula, the Workers' Party and the Governability Dilemma in Brazil" analyses
how the Workers' Party (Partido dos Trabalhadores - PT) coped with the constraints imposed by governability during the two terms of President Lula. Inspired by reflections on the possibilities of the transformative politics of progressive political projects in power, Gómez Bruera certainly shares in what he terms the "great disappointment" in the party's pragmatic changes and the limited reach of the policies pursued, present in the criticisms made by some of those who have studied the PT and the Lula government. As the author states in the Introduction, "given its trajectory, the PT in the national government seemed determined to make a dramatic impact in state-society relationships", but an examination of aspects of the petista agenda shows that "the Lula administration embarked on a very different political path, away from the party's main goals and strategies".

The book promotes a constant dialogue between the party's mobilising and participatory legacy of its formative years, the innovations undertaken in its experiences in local government and the constraints imposed by the interests of dominant strategic actors present in the context of national government. In an attempt to elucidate the ways in which the petista government managed the conflicts caused by the dilemma of governability, the book makes an important contribution towards understanding the strategies of integrating interests within the state.

Given the great production already in existence about the party and its recent transformations, the book's main novelty is this: an approach that essentially focuses on the

* http://dx.doi.org/10.1590/1981-38212014000100006 
relationships with conflicting interests of civil society entered into by the PT in national government. To this end, Gómez Bruera based his work on perceptions and interpretations obtained from 140 interviews held between 2008 and 2010, with actors from the party and members of the wide relations network around it. The work results from a difficult analysis of interpretations by different actors, also based on documents, newspaper articles and surveys from various sources.

The author introduces the notion of governability as a process, that is, the way through which it is attained, and, considering many of its dimensions as being 'highly subjective'(p.08), develops his analysis based on the perceptions and interpretations of political actors.

Although relatively imprecise, this notion of governability contributes towards understanding the dilemma of reconciling conflicting interests according to a particular rationale that moulds the behaviour of left-wing parties in government and is executed by a dynamic that goes beyond the electoral dimension and relations between the executive and legislative spheres.

The features of petista identity are highlighted in his argument - Gómez Bruera focuses not only on the party, but also on the socio-political field around it and their ways of relating to each other. The party socio-political field (the 'PT field', as the author terms it) is a network of wide, informal relations among political and social actors, which includes a large network of cadres, leaders and activists who identify strongly with the party even though they are not members. His thesis is that these types of relations, that have been taking shape since the party's founding, were essential for achieving and guaranteeing wide governability when the party came to power in 2002, as well as for maintaining such ties.

Echoing part of the party literature on the transformations of the Workers' Party after it arrived at the presidency in 2002 (AMARAL, 2010a, 2010b; HUNTER, 2010, 2011), the author ascribes the singular and intense relationship with its social allies to the PT genetic model and, therefore, to the process of formation of its identity.

One of the main arguments regarding the construction of governability refers to the relations between the party and social movements. Herein lies an important contribution made by the book: it helps to understand the relationship dynamics between progressive parties and social movements when state power is reached, in which new forms of involvement with state institutions alter the nature of these relations.

In part, these changes originate from the strengthening of popular representation in public management observed since the early 1990s in many of the Workers' Party subnational experiences of government. These experiences showed the possibility of altering the features of public management through the introduction of innovative actions and actions 
that redefined priorities, among which the Participatory Budget stood out the most. This dynamic expressed the viability of the "PT way of governing", focused on integrating into state institutions the desires and demands structured in civil society. However, transposing these innovations or creating new ones was the challenge lost by the petista government when it came to office at the national level in 2003. To the author, once in power, the PT - seeking wide economic, social and political governability - promoted forms of engagement and participation by civil society "deprived of innovation" (p.118), thus expressing the results of having distanced from its originally counter-hegemonic strategies.

The book is structured in nine chapters and organised in two parts. The first part deals with the years prior to the Lula Government, explains the PT's formative phase, the construction of the "socio-political field", the transformations associated with the prioritisation of electoral politics, and analyses the governability strategies pursued in some petista experiences of local government. The second part deals with the federal government years between 2002 and 2010, analyses the ways in which the party achieved support and strategic actions in the 'PT field', and points out the political resources utilised in the Lula government to accommodate conflicting interests.

In the analysis of the Lula years, the argument develops in several dimensions, dealing with aspects such as the pragmatic administration of economic policy and dominating interests, the prevalence of a technocratic policy design over the original participatory one, and the impositions of electoral logic on the design of policies, specifically, income distribution programmes. The book shows how the governability strategy was fundamentally associated with four elements: the President's strong leadership, the distribution of posts in the state apparatus, the allocation of a massive amount of resources and the existence of ties between personal and party leaders.

Regarding this, the book analyses the relationships that the party established with civil society organisations, maintained through programmatic, interpersonal and reward-related linkages. In the latter case, the distribution of posts among activists and union leaders was crucial for obtaining governability through a recruitment strategy that conditioned the capacity of social organisations to pressure and criticise the government. Another way was through state subsidies. Here, the author argues that the Lula government's willingness to distribute a huge amount of resources engaged civil society organisations into the state dynamic, thus limiting or even avoiding disruptive forms of political action. If that was one way of ensuring social governability, it is also a paradox that, in the presence of a party with a progressive political project, state and social movements entered into a relationship that was potentially constraining of the autonomy of organisations. As the author points out, "this suggests that a process of co-optation may have taken place" (p.145). 
In spite of positive results regarding attaining a congruence of interests, the limitations that governability imposed on wider political transformation are unequivocal. Among the aspects dealt with is the limited introduction of participatory mechanisms at the level of federal policy formation and implementation, which marked, for example, the government's main social policy, the Programa Bolsa Família (Family Grant Programme).

The Lula government made explicit the difficulties in implementing counter-hegemonic actions in political spheres where the complexity of actors and interests is great and varied. Gómez Bruera states that the ways in which the conflict and diversity of interests were managed during the period had significant implications for the transformative potential of progressive politics. His final reflection is that, if at the national level the party developed relying on state power and not on civil society organisations as the main source of change, the reason for this may be not only the government's and the party's strategic decisions, but also civil society's lack of preparedness for the role imagined by the progressive field in the late 1970s (p.174). Particularly because of the developments of these final considerations, it is worth reading the book as a contribution towards reflecting on the limitations of democratic socialism and the possibilities of what came to be known as the 'social left'.

\section{References}

AMARAL, Oswaldo (2010a), As Transformações da Organização do Partido dos Trabalhadores entre 1995 e 2009. Phd Thesis, IFCH/Unicamp.

AMARAL, Oswaldo (2010b), Adaptação e Resistência: o PT no Governo Lula entre 2003 e 2008. Revista Brasileira de Ciência Política, No 04: pp.105-134.

HUNTER, Wendy (2010), The Transformation of the Workers' Party in Brazil (1989-2009). Cambridge: Cambridge University Press.

HUNTER, Wendy (2011), The PT in Power: Shifting Policies and Patterns of Political Support. In: ROBERTS, K.; LEVITSKY, S. (eds.) Resurgence of Latin American Left, Baltimore: Johns Hopkins University Press. 